ppi $201502 Z U 4645$

Esta publicación científica en formato digital es continuidad de la revista impresa ISSN-Versión Impresa 0798-1406 / ISSN-Versión on line 2542-3185Depósito legal pp $197402 Z$ U34
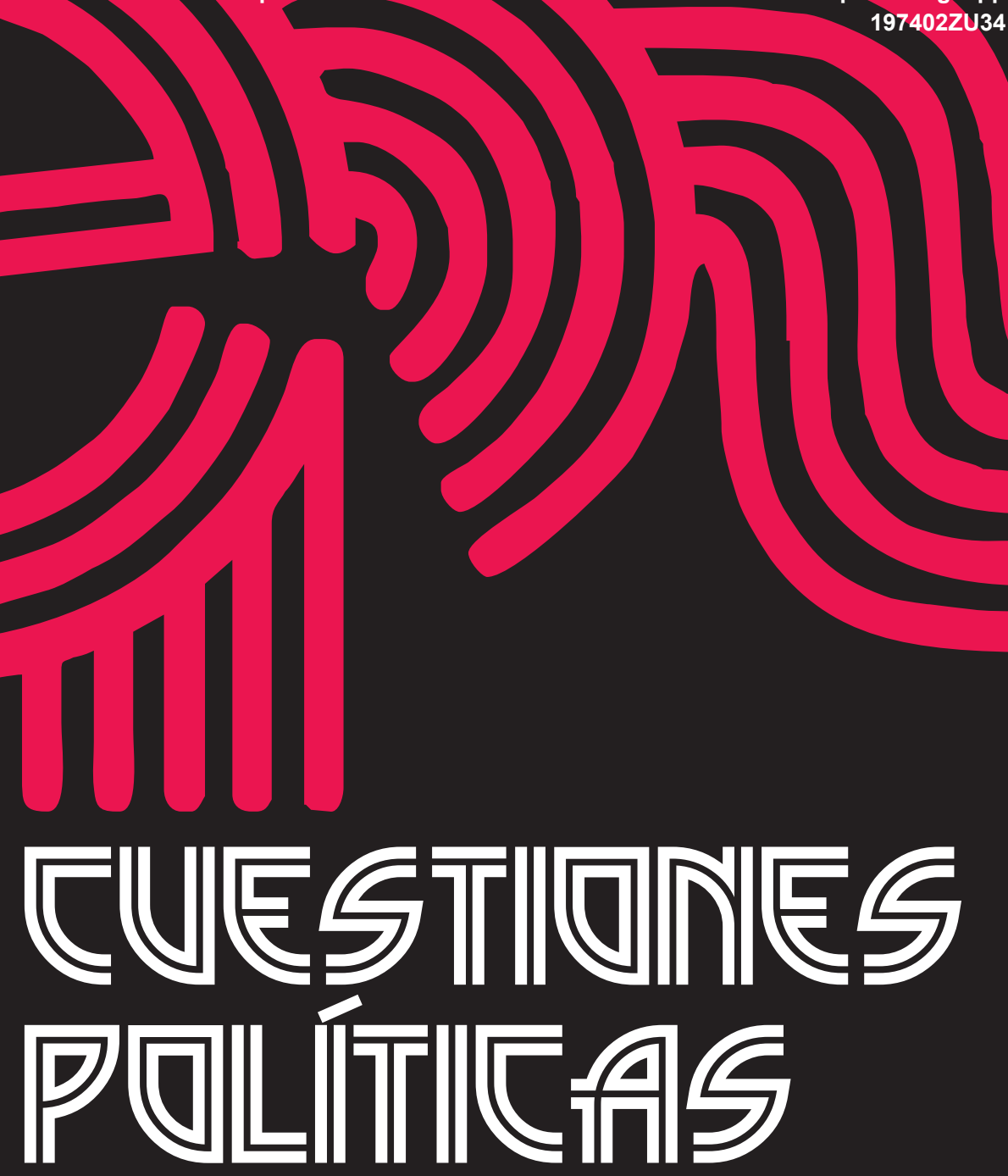

Instituto de Estudios Políticos y Derecho Público "Dr. Humberto J. La Roche" de la Facultad de Ciencias Jurídicas y Políticas de la Universidad del Zulia Maracaibo, Venezuela
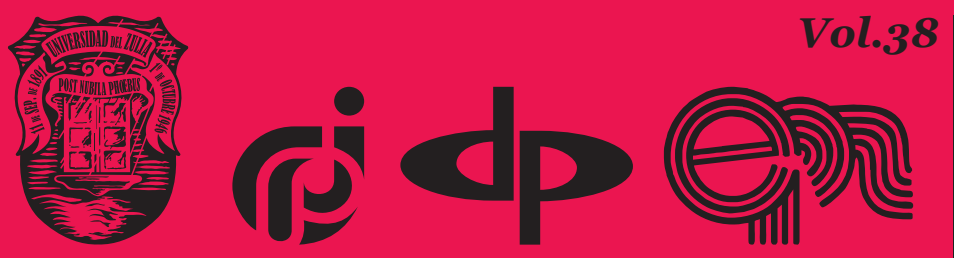

$N^{\circ}$ Especial 2da Parte 2020 


\title{
Implementation of the Function of Maximizing the Security Level in the Administration of Justice in the Digital Economy
}

\author{
DOI: https://doi.org/10.46398/cuestpol.382e.16
}

\author{
Damir Khamitovich Valeev * \\ Anas Gaptraufovich Nuriev **
}

\section{Abstract}

The research analyses the implementation of the role of maximizing the level of security in the administration of justice in the context of the digital economy. Methodologically, the documentary observation research technique and, to process sources, sociological-dialectical analysis were used. Digitization as a transformational factor of many branches of social relations implies dependence on the implementation of a series of interdependent legal facts with digital technologies so that the action has a legal and concrete result. The digital level as a new platform for the implementation of a number of public functions posing new challenges for the public administration system and also determines the status of new functions that can provide a "digital future" with a positive development dynamic. Conclusion mode everything indicates that, these new functions can be austable in order to maximize security in the implementation of public functions in response to new threats. Particularly sensitive is the area of justice administration, which is also actively introducing many digital tools into the case-resolution process.

Keywords: public administration functions; uridic security; idigital information; digital means of trust; right to judicial protection.

Doctor of Law, Deputy Dean for Science Law Faculty of KFU, Honored Lawyer of the Republic of Tatarstan, Kazan Federal University, Author ID: 56180874100, ORCID ID: https://orcid.org/ooooo002-3233-2400. Email: valeev55@gmail.com

** The Constitutional Court of the Republic of Tatarstan, Candidate of Law, Chief of Staff, Kazan Federal University, ORCID ID: https://orcid.org/oooo-0oo1-7373-5938. Email: anasnuriev@yandex.ru 


\section{Implementación de la función de maximización del nivel de seguridad en la administración de justicia en el contexto de la economía digital}

\section{Resumen}

La investigación analiza la implementación de la función de maximización del nivel de seguridad en la administración de justicia en el contexto de la economía digital. En lo metodológico se hizo uso de la técnica de investigacion de observacion documental y, para procesar las fuentes, del análisis sociológico-dialéctico. La digitalización como factor de transformación de muchas ramas de las relaciones sociales implica la dependencia de la implementación de una serie de hechos jurídicos interdependientes con las tecnologías digitales para que la acción emprendida tenga un resultado legal definido y concreto. El plano digital como nueva plataforma para la implementación de una serie de funciones públicas plantea nuevos desafíos para el sistema de administración pública y además determina el surgimiento de nuevas funciones que pueden brindar un "futuro digital" con una dinámica de desarrollo positiva. A modo de conclusión todo indica que, estas nuevas funciones pueden atribuirse al proposito de maximizar la seguridad en la implementación de funciones públicas como respuesta a nuevas amenazas. Particularmente sensible es el área de la administración de justicia, que también está introduciendo activamente muchas herramientas digitales nuevas en el proceso de consideración y resolución de casos.

Palabras clave: funciones de la administración pública; seguridad juridica; información digital; medio digital de confianza; derecho a la protección judicial.

\section{Introduction}

The administration of justice in the new digital realities necessitates the confidentiality of transmitted information and the protection of communication channels, which are becoming a key "digital" link that provides access to justice in a digital economy.

Currently, access to justice can be implemented (including in electronic form) through a symbiosis of platforms that provide a technological algorithm, having legal consequences related to the possibility of initiating a case and its further development in court. The implementation of this opportunity is associated with the general digitalization level and we understand that digital data is becoming a key factor in the development of 
all sectors of public relations as the basis for the transformation of public administration.

As defined in clause 11 of the "Strategy for the Information Society Development in the Russian Federation for 2017-2030" (Decree of the President of the Russian Federation, 2017), the information and communication technologies have become part of modern management systems in all sectors of the economy, in the fields of public administration, national defense, state security and law enforcement. The key tasks are as follows:

- Application by the government bodies of new technologies to improve the quality of public administration.

- Creation of management systems based on information and communication technologies in all fields of public life.

- Use of e-government infrastructure for the provision of public, as well as commercial and non-commercial services demanded by citizens.

\section{Methods}

The methodological basis of the study was formed by the general provisions of the procedural sciences: constitutional law, civil procedural law, administrative procedural law, and criminal procedural law. In the study, the following methods of scientific knowledge were used: interdisciplinary, dialectical, sociological method.

\section{Results and Discussion}

By consolidating the transformation of the public administration model associated with the use of new information and communication technologies, we become dependent on the technological factor and faced with new tasks, which also transform the functions of public administration. Revealing the functions of public administration, the domestic legal doctrine includes the following: 1) collection and processing of social information; 2) forecasting (that is, scientific prediction of changes in the development of any phenomena or processes based on objective data and scientific achievements); 3) planning (that is, determination of areas, goals of management activities and ways, means of achieving these goals); 4) organization (that is, formation of a management system, streamlining 
of managerial relations between the subject and the object, determination of rights and obligations, personnel selection and placement, etc.); 5) regulation or management (that is, establishing a regime of activities to achieve management goals and objectives, regulating the behavior of managed objects, giving directives, etc.); 6) coordination and interaction carried out to achieve common management goals; 7) control and accounting, consisting in establishing whether or not the actual state of the control object corresponds to a given one (Mironov, 2012). The same approach can be found in foreign doctrine (Borodin, 2014).

However, the new "urgent realities" and the digitalization of all sectors of public relations become a prerequisite for the formation of new tasks of public administration, not only on the scale of our state, but it is also becoming a new global trend. As M. Kemal Öktem notes, automation of government-population interaction, the interaction based on nanosecond time intervals, implies innovation in itself. The introduction of innovations using e-government also implies the existence of such a function as protection of confidentiality, information security and electronic transactions, access to online materials, hardware and software, as well as effective technical support (Kemal, 2010). All this testifies to the emergence of new "digital" governmental functions at the present stage of state development, which include maximizing the security level of working with digital data and providing access to it.

The introduction of information and communication technologies in the activities of law enforcement agencies as one of the manifestations of digital transformation of the public administration system requires special control in ensuring the preservation of digital data and the uninterrupted operation of systems that can guarantee data security when exercising the constitutional right to judicial protection. The introduction of digital technology in the administration of justice is primarily intended to simplify access to justice.

As Urszula Nowicka notesin the context of considering the use of electronic communications in the functioning of government bodies, the electronic applications and the electronic deliveries serve to facilitate, streamline and speed up communication procedures between a citizen and government bodies, as well as to reduce their number. Nevertheless, many provisions remain underdeveloped (Urszula Nowicka Electroniccommunication in the functioning of public administration, 2019). In our opinion, the number of such problems should include the implementation of the security level maximization in the administration of justice in the digital economy.

The security level maximization in the administration of justice has always been present as a function, since the state monopoly on resolving conflict situations requires a special approach to resolving disputes at any time requiring prompt external intervention. According to H.H.A Cooper, 
Damir Khamitovich Valeev y Anas Gaptraufovich Nuriev

justice should be administered in a safe environment, as the judiciary and its personal security appear to be at the top of the defense problem. The author emphasizes the need for appropriate specialized training in security issues at all levels (Cooper, 2006). Given the digitalization level, this function should now extend to the virtual plane, which requires close attention within the framework of e-justice at all stages of the case.

The current Russian procedural legislation establishes the possibility of initiating proceedings in court and further influence on the development of procedural relations within the framework of court proceedings on the basis of written appeals drawn up in electronic form by creating an electronic document or an electronic image of a document (P. 1 of Art. 3 of the Civil Procedure Code of the Russian Federation) (Civil Procedure Code of the Russian Federation 1992, 2002); P. 2 of Art. 45 of the Administrative Procedure Code of the Russian Federation (Administrative Procedure Code of the Russian Federation, 2015); P. 1 of Art. 1 of the Criminal Procedure Code of the Russian Federation (Criminal Procedure Code of the Russian Federation dated December 18, 2001).

This procedural opportunity, which involves maximizing the security function in the digital plane, allows talking about digital environment of trust in the procedural relations (Valeev and Nuriev, 2019; Nuriev and Khodzhiev, 2015; Nuriev, 2018). The indicated algorithm is achieved due to the symbiosis of two technological platforms designed to ensure safety in the administration of justice on a digital plane and to disseminate the strict procedural form guaranteed by law for the procedural relations implemented in digital form, and thereby ensuring the implementation of the constitutional right to judicial protection regardless of the data transfer method in relations where one of the mandatory parties is the court:

- "Justice" (electronic court filing system).

- Unified Identification and Authentication System.

In accordance with clause 2.1 of the Order of the Judicial Department at the Supreme Court of the Russian Federation (Order of the Judicial Department under the Supreme Court of the Russian Federation No. 52, 2014), "Justice" is the state automated system of the Russian Federation, which is a geographically distributed automated information system designed to form a single information space of federal courts of general jurisdiction, judicial bodies, as well as bodies of the judicial department system. The Internet portal is located at: https://sudrf.ru/.

The automation objects of "Justice" include (clause 2.3.): SCRF supreme courts of the republics, regional courts, courts of federal cities, courts of the autonomous regions and autonomous okrugs; DMC - district (naval) military courts; DC - district (city) courts; GMC- garrison military courts; CJ - Council of Judges of the Russian Federation; HQCJ - Higher 
Qualification Collegium of Judges of the Russian Federation; HEC - Higher Examination Commission for Admission of the Qualification Exam to the Position of Judge; Judicial Department - Judicial Department under the Supreme Court of the Russian Federation; RBJD - regional bodies of the Judicial Department (branches (offices) of the Judicial Department in the constituent entities of the Russian Federation); FSBI IAC (Federal State Budgetary Institution "Information and Analytical Support Center") of the Judicial Department, its branches.

This automated system, which covers (in addition to the above) information and technical support for the administration of justice in the system of arbitration courts and peace justices, is designed to ensure the security of digital data in the procedural field. As part of the backbone equipment, "Justice" complex of automation tools also includes: server and active network equipment, equipment of the subsystems "Information Security", "Video Conferencing", "Communication and Data Transfer", "Judicial Clerical Work and Statistics", "Collective Information Display Use", including: servers, firewalls, audio recording and audio-video recording complexes of court hearings, witness concealment complexes, information kiosks, video conferencing facilities, switches and routers. At the same time, the general software used is a combination of proprietary software tools creating a software environment that ensures the functioning and information security of "Justice".

Accordingly, the participants in the controversial procedural relationship and the court considering the case creates a digital environment of trust that allows developing procedural relations on a digital plane due to "Justice" platform, designed to maximize the security function in the administration of justice. As expressly stated in the Order of the Judicial Department at the Supreme Court of the Russian Federation No. 251 dated 27.12.2016 (Order of the Judicial Department at the Supreme Court of the Russian Federation No. 251, 2016), the personal account that the parties to the trial use as a tool affecting the development of procedural relations in the digital space is an information resource posted on the court's official website of the "Justice" state automated system (www.sudrf.ru) in the information and telecommunication network "Internet", intended for the implementation of the right to submit documents in electronic form to the court by the trial participants.

"Justice" platform can be accessed by users due to the Unified Identification and Authentication System (UIAS). In accordance with Art. 2 of the Federal Law No. 149 (Federal Law No. 149-FZ "On Information, Information Technologies and Information Protection", 2006), UIAS is a federal state information system, which is operated under the procedure specified by the Government of the Russian Federation and which ensures, in cases stipulated by the legislation of the Russian Federation, authorized access to information contained in the information systems. 
In accordance with the Resolution of the Government of the Russian Federation (Resolution of the Government of the Russian Federation No. 977, 2011), the federal state information system called "unified identification and authentication system in the infrastructure, providing information and technological interaction of information systems used to provide state and municipal services in electronic form" (hereinafter - the Unified Identification and Authentication System) should provide authorized access to the information interaction participants in a single identification and authentication system (hereinafter - the information interaction participants) to the information contained in the state information systems, municipal information systems and other information systems (Valeev et al., 2018; Zuev et al., 2017).

\section{Conclusions}

The introduction of information and communication technologies in the activities of law enforcement agencies as one of the manifestations of digital transformation of the public administration system requires special control in ensuring the preservation of digital data and the uninterrupted operation of systems that can guarantee data security when exercising the constitutional right to judicial protection. Maximizing the security function in the digital plane allows talking about a digital environment of trust in the procedural relations.

The indicated algorithm is achieved due to the symbiosis of two technological platforms ("Justice"; UIAS) designed to ensure safety in the administration of justice on a digital plane and to disseminate the strict procedural form guaranteed by law for the procedural relations implemented in digital form, and thereby ensuring the implementation of the constitutional right to judicial protection regardless of the data transfer method in relations where one of the mandatory parties is the court.

In relation to the administration of justice, the authorized secure access that provides information and technological interaction of information systems used in the administration of justice is carried out through the interaction of "Justice" and UIAS systems, since UIAS provides access to a personal account necessary for working on "Justice" platform using a verified individual account of UIAS. Accordingly, the interaction of these technological platforms makes it possible to maximize the security function in the administration of justice in a digital economy. 


\section{Acknowledgements}

The work is performed according to the Russian Government Program of Competitive Growth of Kazan Federal University.

The reported study was funded by RFBR according to the research project

№ 18-29-16147 мк.

\section{Bibliographic References}

ADMINISTRATIVE PROCEDURE CODE OF THE RUSSIAN FEDERATION, 2015. Official Gazette of the Russian Federation. - dated March 09, 10. - Article - 1391.

BORODIN, Iena. 2014. "The functions of public administration. Scientific works of National Aviation University" In: Series: Law Journal «Air and Space Law». Vol, , pp. 239-259.

CIVIL PROCEDURE CODE OF THE RUSSIAN FEDERATION DATED NOVEMBER 14, 1992 . 2002. Official Gazette of the Russian Federation. - dated November, 18(46), - Art. 4532.

COOPER, Hilton. 2006. "A Securing the Administration of Justice” In: Journal of Security Education. Vol. 1, No. 4, pp. 1-26

CRIMINAL PROCEDURE CODE OF THE RUSSIAN FEDERATION DATED DECEMBER 18. 2001. Official Gazette of the Russian Federation. dated December 24, 52 (Part One). - Art. - 4921.

DECREE OF THE PRESIDENT OF THE RUSSIAN FEDERATION.2017. No. 203. 2017. "On the Strategy for the Development of the Information Society in the Russian Federation for 2017 - 2030" Official Gazette of the Russian Federation. 15.05.2017. No. 20. Art. 2901.

FEDERAL LAW. 2006. No. 149-FZ dated July 27, “On Information, Information Technologies and Information Protection”. 2006. Official Gazette of the Russian Federation dated 31.07.2006. No. 31 (P. 1). Art. 3448.

ÖKTEM, Kemal. 2010. "Innovation with public administration in Turkey" In: Journal of US-China Public Administration. Jan. Vol. 7, No. 1, pp. 42-50. 
Damir Khamitovich Valeev y Anas Gaptraufovich Nuriev

MIRONOV, Andre. 2012. "Public administration: main goals and functions" In: Bulletin of the Moscow University of the Ministry of Internal Affairs of Russia. Vol. 3, pp. 162-164.

NURIEV, Anas. 2018. "Características de la Responsabilidad Civil del Notario” Dilemas contemporáneos: Educación, Política y Valores. Available online. In: https://www.dilemascontemporaneoseducaci onpoliticayvalores.com/index.php/dilemas/article/view/618/1025. Consultation date: 03/05/2020.

NURIEV, Anas; KHODZHIEV, Alisher. 2015. "Procedural guarantees of rights of citizens of the Russian federation in the foreign states" In: Research Journal of Applied Sciences. Vol. 10, No. 12, pp. 832-834.

ORDER OF THE JUDICIAL DEPARTMENT AT THE SUPREME COURT OF THE RUSSIAN FEDERATION. 2016. No. 251, 2016 "On Approving the Procedure for Submitting Documents to the Federal Courts of General Jurisdiction in Electronic Form, Including an Electronic Document Form”. Bulletin of Acts on the Judicial System. 2017. No. 2 (February).

ORDER OF THE JUDICIAL DEPARTMENT UNDER THE SUPREME COURT OF THE RUSSIAN FEDERATION. 2014. No. 52. 2014 "On Approval of the Regulation on Organization of Operation of "Justice" State Automated System of the Russian Federation. "Consultant Plus" Reference Legal System.

RESOLUTION OF THE GOVERNMENT OF THE RUSSIAN FEDERATION. 2011. No. 977 dated 28.11.2011 "On the federal state information system called "unified identification and authentication system in the infrastructure, providing information and technological interaction of information systems used to provide state and municipal services in electronic form" (2011). Official Gazette of the Russian Federation dated 05.12.2011. No. 49 (P. 5). Art. 7284.

URSZULA NOWICKA ELECTRONICCOMMUNICATION IN THE FUNCTIONING OF PUBLIC ADMINISTRATION. 2019. Uniwersytet Przyrodniczo-Humanistyczny w Siedlcach. Issue: RAIP 2019; specjalny (XIX). Pp/ 203-220.

VALEEV, Damir; NURIEV, Anas; SHAKIRJANOV, Rafael. 2018. "Implementación del derecho constitucional a la protección judicial en los idiomas estatales del sujeto de la Federación Rusa" In: Dilemas contemporáneos: Educación, Política y Valores. Available online. In: https://www.dilemascontemporaneoseducacionpoliticayvalores. com/index.php/dilemas/article/view/668/1018. Consultation date: 03/05/2020. 
VALEEV, Damir; NURIEV, Anas. 2019. "Digital confidence environment in procedure relationships" In: Revista Genero \& Direito. Vol. 8, No. 6, pp. 42-49

ZUEV, Dmitry; MARCHENKO, Alexandr; KHASYANOV, Alex. 2017. The use of text intellectual analysis tools in jurisprudence. In the collection: analytics and data management in the areas with heavy data usage. Collection of scientific papers of the XIX International Conference DAMDID / RCDL'2017. Ed. by L.A. Kalinichenko, Y. Manolopoulos, N.A. Skvortsov, V.A. Sukhomlin, 277-281. 
Vol.38 NEspecial

Esta revista fue editada en formato digital y publicada en diciembre de 2020, por el Fondo Editorial Serbiluz, Universidad del Zulia. Maracaibo-Venezuela 